\title{
I Zimowa Szkoła Historii Najnowszej 27 lutego - 3 marca 2012 roku
}

W dniach 27 lutego - 3 marca 2012 r. (poniedziałek - sobota) odbyła się, zorganizowana przez Instytut Pamięci Narodowej, I Zimowa Szkoła Historii Najnowszej. Biuro Edukacji Publicznej IPN, po pięciu edycjach Szkoły Letniej, postanowiło zorganizować także edycję zimową.

Zgodnie z założeniami Szkoła przeznaczona jest dla doktorantów, a w wyjątkowych wypadkach także dla studentów starszych lat, podejmujących w swoich badaniach problematykę związaną z najnowszymi dziejami Polski. Najliczniej reprezentowany był wrocławski ośrodek historyczny. Ośrodek białostocki reprezentował Przemysław Kowalski, student V roku i jednocześnie jedyny reprezentant wydziałów prawa.

W programie Szkoły znalazły się przede wszystkim wykłady wybitnych badaczy historii najnowszej. Wykład inaugurujący pt. „«Ludzie i system» w PRL i gdzie indziej: o wyjaśnianiu dziejów najnowszych", wygłosił prof. Dariusz Stola. Następnego dnia, we wtorek, prof. Andrzej Friszke przybliżył powstanie KOR w 1976 r. i rozszerzył wystąpienie (m.in. na skutek żywego zainteresowania i pytań uczestników) o działalność Komitetu w dalszych latach. W środę z kolei miał wystąpienie prof. Andrzej Paczkowski („«Żydokomuna» - mity i rzeczywistośc"). W czwartek uczestnicy Szkoły wysłuchali dwóch wykładów. Najpierw dr hab. Piotr Majewski przybliżył ideę Muzeum II Wojny Światowej i jej praktyczną realizację. Następnie prof. Rafał Stobiecki wygłosił wykład pt. „Metodologia historii - czym jest i dlaczego jest nam potrzebna”. Piątkowy, ostatni wykład, dotyczący dylematów historyka dziejów najnowszych, zaprezentował prof. Antoni Dudek. Podsumowując tę część programu Szkoły, należy podkreślić, że prawie wszyscy prelegenci bardzo chętnie kontynuowali wielogodzinne dyskusje nad referatami.

Kolejną ważną częścią programu Szkoły były warsztaty, a przeprowadzili je: dr Grzegorz Waligóra („Wykorzystanie dokumentów SB w badaniach historycznych”), Wiesława Młynarczyk („Jak uczyć o Holokauście? Ważne źródła i metody”), dr Joanna Wawrzyniak („Historia mówiona - sztuka rozmowy”) oraz dr Rafał Stefański („Prowadzenie spotkań i prezentacji”).

Uczestnicy wzięli też udział w dyskusji panelowej dotyczącej historii mówionej, a jej moderatorem był Jan Olaszek.

Każdy z uczestników miał za zadanie przygotować oraz zaprezentować dwudziestominutowy referat dotyczący aktualnych planów badawczych, tudzież realizowanych prac. Wystąpienia przedstawiane były w ramach seminariów prowadzonych przez Prezesa IPN, dra Łukasza Kamińskiego. Odbywały się one codziennie, z sobotą włącznie. Podkreśla to znaczenie, jakie władze IPN przykła- 
dają do kształcenia młodych badaczy historii najnowszej. Tematyka wystąpień była bardzo bogata. Wygłoszone zostały następujące referaty (w kolejności chronologicznej): Grzegorz Rutkowski, Udział Batalionów Chłopskich w odbiorze zrzutów lotniczych na terenie okupowanej Polski (1939-1945); Daníel Hanik, Losy polskich uchodźców na terenie I Republiki Stowackiej w 1944 roku; Magdalena Kazik, Postawy polskich historyków wobec konfliktu polsko-ukraińskiego w czasie II wojny światowej; Milena Bykowska, Ludwik Danielak „Bojar” (1923-1955) żotnierz Konspiracyjnego Wojska Polskiego; Dominika Pasik, Działalność II konspiracji na terenie Wolbromia w latach 1948-1950; Agata Stolarz, Pamięć jako źródło historyczne. „Historia mówiona” w warsztacie historyka mentalności; Tomasz Siewierski, Mimo wszystko bliżej Marksa niż Stalina... Inspiracje marksistowskie w twórczości Mariana Małowista; Sławomir Józefiak, Cztery dekady na komunistycznej uwięzi. Główne kierunki przemian inteligencji polskiej w Litewskiej SRR w latach 1948-1988; Michał Przeperski, „W walce o realizacje październikowej linii partii”. Publicystyka Mieczysława F. Rakowskiego w latach 1957-1961; Artur Bilski, Stan polskiego sportu w latach czterdziestych XX wieku; Wojciech Paduchowski, Narodziny Nowej Huty - spór o geneze decyzji o budowie Nowej Huty w rejonie krakowskim; Paweł Piecyk, Działalność Powiatowego Komitetu Obrońców Pokoju w Bolesławcu w latach 1950-1953 w świetle dokumentów Wojewódzkiego Komitetu Obrońców Pokoju we Wrocławiu; Łukasz Wolak, Zjednoczenie Polskich Uchodźców w Republice Federalnej Niemiec w latach 1950/51-1954. Pierwsze trudne lata działalności organizacyjnej; Karolina Oczko, Przesiedlenie ludności polskiej $z$ województwa tarnopolskiego w latach 1945-1946 w świetle raportów Obwodowej Delegatury Rządu RP na Kraj w Czortkowie; Marcin Myśliński, Sytuacja na Ziemiach Odzyskanych w pierwszych latach po II wojnie światowej na przykładzie miejscowości Dobrodzień; Tomasz Kędra, Sytuacja materialna ludności polskiej na Dolnym Ślasku w latach 1945-1950; Maciej Siwicki, Stosunek władzy do obiektów zabytkowych w województwie zielonogórskim w latach 1950-1975; Anna Brojer, Kościót katolicki wobec głównych problemów obyczajowości małżeńskiej w Polsce lat siedemdziesiątych; Przemysław Kowalski, Reforma ustroju i prawa PRL w posierpniowych postulatach białostockiej palestry; Agnieszka Jaworska, Pomarańczowa Alternatywa we Wrocławiu. Wygłoszone przez uczestników referaty zostaną opublikowane w formie książkowej.

$\mathrm{Na}$ koniec zajęć uczestnicy otrzymali, wręczane osobiście przez Prezesa dra Ł. Kamińskiego, zaświadczenia o ukończeniu I Zimowej Szkoły Historii Najnowszej.

Oceniam Szkołę jako autentyczny sukces organizacyjny. Świadczą o tym zarówno wykłady, jak i wystąpienia uczestników. Żywe dyskusje, jakie wywiązywa- 
ły się po wystąpieniach, powodowały regularne wydłużanie zajęć. Nikt jednak się nie skarżył. Nad całą sferą organizacyjną owocnie czuwała p. Anna Piekarska (BEP IPN). Z kolei Biały Pałac w Palczewie k. Warki to godne polecenia miejsce na organizowanie takich wydarzeń.

Szkoła okazała się pożytecznym doświadczeniem dla młodych badaczy. Kontakty $\mathrm{z}$ naukowcami będą wykorzystywane $\mathrm{w}$ przyszłych pracach naukowych. Należy mieć nadzieję, że wobec tylu udanych edycji Szkól, IPN będzie kontynuował ten program.

Na koniec jeszcze jedna konstatacja: z perspektywy historycznoprawnej można tylko żałować, że spotkania historyków prawa $\mathrm{z}$ historykami odbywają się tak rzadko. 